\title{
Lymphoid Blood-Forming Cell
}

National Cancer Institute

\section{Source}

National Cancer Institute. Lymphoid Blood-Forming Cell. NCI Thesaurus. Code C13012.

A lymphoid blood-forming cell is a hematopoietic stem cell that is a precursor for a $\mathrm{T}$ lymphocyte or B lymphocyte. 